\title{
PENGEMBANGAN MAJALAH BIOLOGI (BIOMAGZ) \\ PADA MATERI VIRUS SEBAGAI ALTERNATIF SUMBER \\ BELAJAR MANDIRI SISWA KELAS X DI MAN 1 MATARAM
}

\section{Development of Biology Magazine (Biomagz) \\ On Virus Material as an Alternative Self-Learning Resources in $X^{\text {th }}$ grade Students of MAN 1 Mataram}

\author{
Husnul Budiatman Dani' ${ }^{1}$, Yahdi ${ }^{2}$, Hadi Kusuma Ningrat ${ }^{3}$ \\ 1,2,3 Pendidikan Biologi FITK UIN Mataram, Mataram, NTB, Indonesia \\ email : buddyatman@gmail.com
}

\begin{abstract}
This study aims to examine the quality of application of biology magazine as an alternative self-learning resource for $10^{\text {th }}$ year students in MAN 1 Mataram on Virus Material. This is a research and development study using ADDIE model which consist of Analysis, Design, Development and Implementation as well as Evaluation. To assest the quality of Biology Magazine (BioMagz), This was determined by assessment sheets (questionnaire) covering components includes the material/ content feasibility, linguistic and presentation. This Biology Magazine (BioMagz) was applied to 15 students of the $10^{\text {th }}$ year in MAN 1 Mataram. The result showed that there was a significant different in learning outcomes of students whom Biology Magazine (Biomagz) was applied compared to students whom was conventional resoursce applied. This was shown by assessments of content completeness which was excellent with scores $100 \%$, and Media worthiness reached scores $96 \%$ which was excellent, while evaluation result of field trials was good with scores $77,5 \%$. This study suggested that Biology Magazine (BioMagz) can be used as an alternative self-learning resource to learn virus material in school.
\end{abstract}

Keywords : Learning Resource, Biology Magazine, Research, Development. 


\section{PENDAHULUAN}

Perkembangan ilmu pengetahuan dan teknologi semakin mendorong inovasi dalam pemanfaatan teknologi sebagai media sumber belajar. Para guru dituntut agar mampu menggunakan media yang dapat disediakan sekolah serta mengidentifikasi berbagai sumber belajar yang dapat menunjang tujuan pengajaran. Disamping itu, guru harus membuat sumber yang ada efektif dan berusaha menemukan sumber belajar yang tersedia tetapi belum dimanfaatkan (Azhar, 2013).

Keberhasilan pembelajaran sangat bergantung pada penggunaan sumber belajar yang sesuai, dapat memenuhi tujuan pembelajaran, yaitu memotivasi, menarik perhatian, dan menstimulasi siswa melalui materi pembelajaran (Trianto, 2010). Menurut Permendiknas RI No. 2 Tahun 2008 Pasal 1 Ayat 3, menjelaskan bahwa buku pendidikan bertujuan memberikan pengalaman, pengetahuan, keterampilan, kepada siswa tentang kehidupan dalam berbagai bidangnya, baik tentang dunia, masyarakat, budaya dan alam sekitarnya maupun tentang Tuhan Yang Maha Esa. Hal ini menunjukkan betapa pentingnya buku bagi siswa. Keberadaan buku sangat berpengaruh terhadap proses pembelajaran.

Siswa seringkali terjebak dalam kondisi pembelajaran yang verbalistik. Keadaan yang demikian dapat dicegah jika guru menggunakan alat bantu, bahkan siswa akan menjadi lebih aktif dan berprestasi dalam proses belajar, misalnya menggunakan rekaman. Demikian pula, jika guru memanfaatkan media visual seperti buku, gambar, peta bagan, film, model dan alat-alat demonstrasi, maka siswa akan belajar lebih efektif. Hal ini karena sesuatu yang dilihat akan memberikan kesan yang lebih lama, lebih mudah diingat, dan mudah pula dipahami (Oemar, 2008).

Guru dintuntut untuk kreatif mencari serta mengumpulkan sumber dan membuat bahan ajar yang diperlukan dalam pembelajaran. Namun terkadang guru belum mampu membuat bahan ajar maupun media belajar sendiri. Seperti yang di sampaikan Mulyasa (2014), bahwa kreativitas guru dan peserta didik perlu senantiasa ditingkatkan untuk membuat dan mengembangkan alat-alat pembelajaran serta alat peraga lain yang berguna bagi peningkatan kualitas pembelajaran. Kreativitas 
tersebut diperlukan, semata-mata karena keterbatasan fasilitas dan dana dari pemerintah, tetapi merupakan kewajiban yang harus melekat pada setiap guru untuk berkreasi, berinprovisasi, berinisiatif dan inovatif.

Salah satu materi pelajaran biologi kelas X adalah virus. Virus merupakan partikel penginfeksi yang terdiri dari asam nukleat yang terbungkus di dalam lapisan pelindung dan di beberapa kasus di dalam selubung membran. Pemaparan tentang virus seperti inilah di benak siswa masih sulit dipahami, apalagi dengan istilah-istilah atau bahasa latin yang jumlahnya tidak sedikit.

Berdasarkan hasil observasi dan wawancara pada siswa, materi virus menurut siswa cukup membingungkan dan sulit dipahami, sedangkan sumber belajar yang tersedia di sekolah tidak memenuhi kebutuhan belajar siswa dibuktikan bahwa pada saat peneliti melaksanakan kegiatan Praktek Pengajaran, sumber belajar berupa buku atau LKS jumlahnya sangat terbatas. Sehingga siswa kebanyakan mencari materi dengan menggunakan internet, selain itu siswa mengeluhkan tampilan sumber belajar siswa yang tersedia kurang menarik.

Salah satu media yang bisa mendukung dan membantu proses belajar adalah media visual seperti majalah. Majalah sudah terkenal dan banyak beredar di kalangan anak remaja, akan tetapi bentuknya hanya menampilkan sebuah produk dan informasiinformasi tentang artis maupun perkembangan ilmu teknologi, jarang sekali ditemukan majalah yang berlatar belakang dunia pendidikan. Padahal majalah bisa dijadikan alternatif sumber belajar karena bentuk yang disajikan dalam majalah itu menarik dan memberikan informasi yang ditail.

Berdasarkan hal tersebut di atas maka diadakan penelitian dan pengembangan sumber belajar cetak berupa majalah biologi (biomagz) yang dapat digunakan sebagai alternatif sumber belajar mandiri. Majalah ini memuat materi biologi untuk siswa kelas $\mathrm{X}$ SMA/MA yaitu materi virus. Majalah biologi (biomagz) yang diharapkan dapat menjadi alat bantu pembelajaran agar memenuhi tujuan pembelajaran siswa kelas X SMA/MA pada materi virus di MAN 1 Mataram. 


\section{METODE PENELITIAN}

\section{Prosedur Pengembangan}

Model pengembangan yang digunakan dalam pengembangan majalah biologi (biomagz) ini adalah model pengembangan ADDIE yaitu Analysis, Design, Development, Implementation dan Evaluation. Pemilihan model ini didasari atas pertimbangan bahwa model ini dikembangkan secara sistematis dan berpijak pada landasan teoritis desain pembelajaran. Model ini disusun secara terprogram dengan urutan-urutan kegiatan yang sistematis dalam upaya pemecahan masalah belajar yang berkaitan dengan sumber belajar yang sesuai dengan kebutuhan dan karakteristik pelajar. Model ini terdiri atas lima langkah, yaitu: (1) Analysis, (2) Design, (3) Development, (4) Implementation, dan (5) Evaluation. Secara visual tahapan ADDIE model dapat dilihat pada gambar di bawah ini.

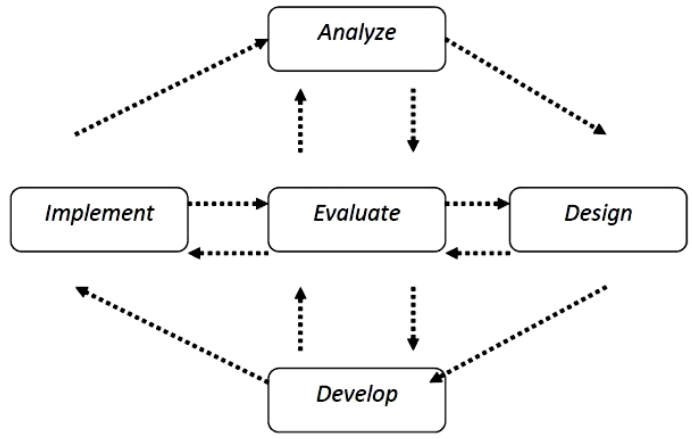

\section{Gambar 1. Pendekatan ADDIE untuk Mengembangkan Produk yang Berupa Sumber Belajar.}

\section{Uji Coba Produk}

Uji coba produk dimaksudkan untuk mengumpulkan data yang dapat dipergunakan sebagai dasar untuk menetapkan tingkat efektivitas, efisiensi, dan daya tarik produk yang dihasilkan.

1. Desain Uji Coba

Uji coba produk sangat penting dilakukan untuk mengetahui kualitas sumber belajar yang dihasilkan. Oleh karena itu perlu dilakukan uji coba kepada sasaran produk yang dikembangkan. Sebelum diujicobakan, produk berupa majalah biologi (biomagz) divalidasi terlebih 
dahulu oleh ahli materi dan ahli media, kemudian dilakukan revisi tahap I. Kemudian dilaksanakan revisi tahap II.

2. Subjek Uji Coba

Subjek uji coba produk berupa majalah biologi (biomagz) adalah 15 orang siswa MAN 1 Mataram kelas X.

3. Waktu Uji Coba

Validasi ahli materi dilakukan di sekolah MAN 1 Mataram oleh guru pengajar mata pelajaran biologi dan ahli media dilakukan di Institut Agama Islam Negeri Mataram oleh dosen pengampu mata kuliah media pembelajaran pada bulan juni 2016.

\section{Jenis Data}

Sesuai dengan tujuan penelitian pengembangan ini, data yang dikumpulkan terdiri dari dua macam yaitu:

1. Data mengenai proses pengembangan majalah biologi (biomagz) sebagai alternatif sumber belajar mandiri siswa pada materi virus kelas X SMA/ MA ini sesuai dengan prosedur yang telah ditentukan. Data ini berasal dari penilaian dan masukan ahli materi dan ahli media.

2. Data tentang tanggapan siswa terhadap majalah biologi (biomagz) sebagai alternatif sumber belajar mandiri siswa pada materi virus kelas X SMA/ MA berdasarkan uji coba kelayakan oleh siswa.

\section{Instrumen Pengumpulan Data}

Pada penelitian ini instrumen yang digunakan dalam pengumpulan datanya adalah sebagai berikut:

a) Dokumentasi

b) Angket. Adapun angket yang digunakan adalah sebagai berikut: (1) angket tanggapan dan penilaian ahli isi atau materi tentang virus; (2) angket tanggapan dan penilaian ahli media pembelajaran; (3) angket tanggapan siswa terhadap kelayakan majalah biologi (biomagz) yang sudah di validasi oleh ahli materi dan ahli media.

c) Wawancara 


\section{Analisis Data}

Pedoman penilaian (skor) skala Likert digunakan untuk merubah data kualitatif menjadi kuantitatif.

Tabel 1.

Pedoman Skor Penilaian

\begin{tabular}{|c|c|}
\hline Data Kualitatif & Skor \\
\hline SB (Sangat Baik) & 5 \\
\hline B (Baik) & 4 \\
\hline C (Cukup) & 3 \\
\hline K (Kurang) & 2 \\
\hline $\begin{array}{c}\text { SK (Sangat } \\
\text { Kurang) }\end{array}$ & 1 \\
\hline
\end{tabular}

Keberhasilan produk diukur menggunakan indeks persentase lalu dikonversikan sesuai table 2 , sebagai berikut :

$$
\text { Indeks } \%=\frac{\text { Jumlah skor }}{\text { Jumlah skor tertinggi }} \times 100 \%
$$

Selanjutnya, untuk menghitung persentase keseluruhan subyek digunakan rumus:

$$
\mathrm{P}=\frac{\sum p}{\sum n} \times 100 \%
$$

Keterangan:

$\mathrm{P} \quad=$ Presentase penilaian

$\Sigma \mathrm{p}=$ Jumlah skor $\mathrm{x}$ Frekuensi jawaban

$\sum \mathrm{n}=$ Jumlah skor tertinggi $\mathrm{x}$ jumlah siswa.

\section{Tabel 2.}

Konversi Tingkat Kelayakan

\begin{tabular}{|c|c|c|}
\hline Interval & Kualitatif & Keterangan \\
\hline $0 \%-54 \%$ & Tidak valid & Direvisi \\
\hline $55 \%-64 \%$ & Kurang & Direvisi \\
\hline $65 \%-74 \%$ & Cukup & Direvisi \\
\hline $75 \%-89 \%$ & Valid & Tidak perlu revisi \\
\hline $90 \%-100 \%$ & Sangat valid & Tidak perlu revisi \\
\hline
\end{tabular}




\section{Hasil Penelitian}

1. Hasil Uji Ahli Isi

Produk pengembangan ini berupa majalah biologi (biomagz) sebagai alternatif sumber belajar mandiri siswa pada materi virus di kelas X SMA/MA. Untuk uji validasi isi/materi majalah Biologi ini, ahli isi/materi (validator isi) yang digunakan adalah guru tetap MAN 1 Mataram. Hasil responden ahli materi/isi, maka harus diketahui dahulu skor tertinggi $(\mathrm{X})$ dan skor terendah $(\mathrm{Y})$ untuk item penilaiannya, yaitu:

(X) Jumlah skor ideal/ skor teringgi adalah $: 5 \times 15=75$

(Y) Jumlah skor terendah adalah $\quad: 1 \times 15=7$

Berdasarkan jumlah skor tertinggi (X) yang diperoleh, maka tingkat kelayakan menurut ahli isi terhadap majalah biologi (biomagz) sebagai alternatif sumber belajar mandiri siswa pada materi virus kelas X SMA/MA dapat dihitung dengan menggunakan rumus Skala Likert yaitu:

$$
\begin{aligned}
\text { Indeks \% } & =\frac{\text { Jumlah skor }}{\text { Jumlah skor tertinggi }} \times 100 \% \\
& =\frac{75}{75} \times 100 \% \\
& =100 \%
\end{aligned}
$$

Setelah dikonversikan dengan tabel konversi dan memenuhi masukan, kritik serta saran ahli materi/isi menunjukkan bahwa produk pengembangan berupa majalah biologi (biomagz) berada dalam kualifikasi sangat valid dan tidak perlu direvisi lagi.

\section{Hasil Uji Ahli Media}

a. Penyajian dan Analisis Data Produk Pengembangan Sebelum Direvisi

Berdasarkan teknik pengumpulan data dengan menggunakan instrument angket, dimana terdapat 7 kriteria pernyataan dengan total item 15 pernyataan yang diajukan pada ahli media, kemudian hasil yang didapat tersebut direkapitulasi untuk mengetahui tingkat kelayakan majalah 
biologi (biomagz)sebagai alternatif sumber belajar mandiri siswa pada materi virus kelas X SMA/MA.

Untuk mendapatkan hasil responden ahli media, maka harus diketahui dahulu skor tertinggi (X) dan skor terendah (Y) untuk item penilaiannya, yaitu:

(X) Jumlah skor ideal/ skor teringgi adalah $: 5 \times 15=75$

(Y) Jumlah skor terendah adalah $\quad: 1 \times 15=7$

Berdasarkan jumlah skor tertinggi (X) yang diperoleh, maka tingkat kelayakan menurut ahli media terhadap penggunaan majalah biologi (biomagz) sebagai alternatif sumber belajar mandiri siswa pada materi virus kelas X SMA/MA dapat dihitung dengan menggunakan rumus Skala Likert yaitu:

Indeks \%

$$
\begin{aligned}
& =\frac{\text { Jumlah skor }}{\text { Jumlah skor tertinggi }} \times 100 \% \\
& =\frac{58}{75} \times 100 \% \\
& =77 \%
\end{aligned}
$$

Setelah dikonversikan dengan tabel konversi menunjukkan bahwa produk pengembangan berupa majalah biologi (biomagz) sebagai alternatif sumber belajar mandiri siswa pada materi virus kelas X SMA/MA berada dalam kualifikasi valid.

\section{b. Penyajian dan Analisis Data Produk Pengembangan Setelah Direvisi}

Berdasarkan penilaian cetakan kedua produk yaitu majalah biologi maka tidak perlu lagi dilakukan revisi. Karena persentase kelayakan pada produk pengembangan majalah biologi (biomagz) sebagai alternatif sumber belajar mandiri siswa pada materi virus kelas X SMA/MA dalam kategori valid. Adapun hasil review dari ahli media serta perbaikan yang dilakukan berdasarkan masukan, saran dan komentar ahli media sebagai berikut:

Untuk mendapatkan hasil responden ahli media, maka harus diketahui dahulu skor tertinggi (X) dan skor terendah (Y) untuk item penilaiannya, yaitu:

(X) Jumlah skor ideal/ skor teringgi adalah $\quad: 5 \times 15=75$ 
(Y) Jumlah skor terendah adalah

$$
: 1 \times 15=7
$$

Berdasarkan jumlah skor tertinggi (X) yang diperoleh, maka tingkat kelayakan menurut ahli media terhadap penggunaan majalah biologi (biomagz) sebagai alternatif sumber belajar mandiri siswa pada materi virus kelas $\mathrm{X}$ SMA/MA dapat dihitung dengan menggunakan rumus Skala Likert yaitu:

Indeks \%

$$
\begin{aligned}
& =\frac{\text { Jumlah skor }}{\text { Jumlah skor tertinggi }} \times 100 \% \\
& =\frac{72}{75} \times 100 \% \\
& =96 \%
\end{aligned}
$$

Setelah dikonversikan dengan tabel konversi dan memenuhi masukan, kritik serta saran ahli media sehingga menunjukkan bahwa produk pengembangan berupa majalah biologi (biomagz) sebagai alternatif sumber belajar mandiri siswa pada materi virus kelas X SMA/MA berada dalam kualifikasi sangat valid.

\section{Hasil Uji Coba Produk}

Hasil review berdasarkan saran, masukan dan komentar para ahli dalam angket penilaian hasil produk pengembangan yang berupa majalah biologi. Maka selanjutnya di berikan kepada siswa dan sekaligus dilakukan uji lapangan. Uji coba produk dilakukan di MAN 1 Mataram yang berjumlah 43 siswa dalam satu kelas yaitu X IIS1. Namun uji coba yang dilakukan menggunakan sampel yaitu 15 orang siswa. Produk pengembangan yang di uji coba pada siswa berupa pengembangan majalah biologi (biomagz) sebagai alternatif sumber belajar mandiri siswa pada materi virus. Selanjutnya siswa di berikan angket tanggapan setelah menggunakan majalah biologi untuk penilaian hasil uji coba lapangan.

\section{a. Data Tanggapan Siswa Terhadap Majalah Biologi}

Berdasarkan penilaian/tanggapan sebagaimana tercantum dalam tabel di atas, diketahui bahwa rata-rata persentase tingkat pencapaian majalah biologi (biomagz) sebagai alternatif sumber belajar mandiri siswa pada materi virus 
untuk kelas X SMA/MA yaitu 77,5\% dan dikonversikan dengan tabel kelayakan berada pada kualifikasi valid.

\section{b. Data Prestasi Belajar Siswa Setelah Menggunakan Majalah Biologi (Biomagz)}

Hasil analisis statistik dengan uji $t$ diperoleh nilai $P$ value $(0,000<0,05)$, maka perbedaan antara rata-rata nilai hasil belajar siswa yang menggunakan majalah biologi (biomagz) dengan rata-rata nilai hasil belajar siswa yang tidak menggunakan majalah biologi (biomagz). Data hasil belajar siswa diperoleh rata-rata (mean) untuk siswa yang menggunakan majalah biologi (biomagz) adalah 85,64 dan untuk siswa yang tidak menggunakan majalah biologi (biomagz) adalah 71,79, artinya bahwa rata-rata nilai hasil belajar siswa yang menggunakan majalah biologi (biomagz) lebih tinggi dari pada rata-rata nilai hasil belajar siswa yang tidak menggunakan majalah biologi (biomagz).

\section{Kesimpulan}

1. Dari hasi review ahli materi/isi mendapatkan nilai sebesar $100 \%$ yang berarti produk dalam kategori sangat valid, hasil review ahli media mendapatkan nilai sebesar 96\% yang berarti produk pengembangan dalam kategori sangat valid, dan dari hasil tanggapan siswa setelah menggunakan majalah biologi atau pada tahap uji coba lapangan mendapatkan persentase hasil penilain/tanggapan sebesar 77,5\% yang berarti produk pengembagan dinyatakan valid atau layak digunakan sebagai sumber belajar siswa.

2. Hasil analisis statistic menggunakan uji t diperuleh nilai $p=0,000<p=0,05$, terdapat perbedaan yang signifikan antara siswa menggunakan majalah biologi (biomagz) dan yang tidak.

\section{DAFTAR PUSTAKA}

Andriyani, F. (2014). Pengaruh Penggunaan Majalah Sebagai Media Pembelajaran Terhadap Minat dan Prestasi Belajar 
Pendidikan Kewarganegaraan Siswa Kelas XI IPA SMA Negeri 1 Seyegan. Skripsi. Yogyakarta: UNY.

Arsyad, A. (2013). Media Pembelajaran. Jakarta: PT Raja Grafindo Persada.

Asril, Z. (2013). Micro Teaching: Disertai dengan Pedoman Pengalaman Lapangan. Jakarta: Rajawali Pers.

Emzir. (2014). Metodologi Penelitian Pendidikan Kuantitatif dan Kualitatif. Jakarta: Rajawali.

Hamalik, O. (2008). Perencanaan Pembelajaran Berdasarkan Pendekatan Sistem. Jakarta: Bumi Aksara.

Irianto, K. (2013). Mikrobiologi: Meguak Dunia Mikroorganisme jilid 1. Bandung: Yrama Widya.

Isnaini, E. (2014). Pengembangan Sumber Belajar IPS Bentuk Majalah dengan Materi Interaksi Manusia dan Lingkungan Untuk Siswa Kelas VII SMP. SKRIPSI. UNY.

Musfiqon. (2012). Pengembangan Media dan Sumber Pembelajaran. Jakarta: Prestasi Pustaka Publisher.

Muslim, SB. (2013). Supervisi Pendidikan Meningkatkan Kualitas Profesionalisme Guru. Mataram: CV. Alfabeta.

Ngalim, P. (2010). Prinsip-Prinsip dan Teknik Evaluasi Pengajaran. Bandung: PT Remaja Rosdakarya.

Pelaczar J Michael \& Chan E.C.S. (2013). Dasar-Dasar Mikrobiologi 1. Jakarta: UI-Press.

Prastowo, A. (2015). Panduan Kreatif Membuat Bahan Ajar Inovatif. Jogjakarta: Diva Press. 
Putra, MS. (2008). Memulai \& Mengelola Majalah Sekolah. Jakarta: Macanan Jaya Cemerlang.

Ratman, FA. (2005). Virologi. Surabaya: Airlangga University Pers.

Sadirman., dkk. (2014). Media Pendidikan: Pengertian, Pengembangan, dan Pemanfaatannya. Jakarta: Rajawali Pers.

Sanjaya, W. (2012). Media Komunikasi Pembelajaran. Jakarta: Kencana.

Setyosari. (2015). Metode Penelitian Pendidikan dan Pengembangan. Jakarta: Kencana Prenada Media Grup. 